\title{
Japan reaches out
}

\section{Tokyo}

IN its annual policy statement, the Japanese Science and Technology Agency (STA) recommends globalizing Japan's scientific and technological research to counteract a perceived movement toward protectionism in Western countries, in particular the United States. The white paper closely echoes the policy of 'technoglobalism' announced by the Ministry of International Trade and Industry (MITI) last year, and indicates that Japan is serious about internationalizing its research activities.

The document, submitted to the Cabinet last Friday, says the country should follow this course "even if there should occur protectionist attitudes in view of the steady advance of Japan", because globalization is a "plus sum game" from which "all can benefit in the long run".

Such internationalization has already begun, the white paper shows. Since the mid-1980s, many Japanese high-technology companies have established overseas research and development centres. An STA official says there are now 276 such facilities, mainly in the United States and Western Europe. Most of the research institutes are fairly small, with fewer than 50 researchers, but the agency found that many of them plan to expand to 50 to 100 researchers by the mid-1990s.

The electronics company NEC, for instance, recently established a small basic research institute in Princeton, New Jersey, in the United States. NEC officials say they received a flood of applications from high-quality researchers, many of them from leading US industrial research centres. Now NEC is planning to set up another research centre in Europe, in either Germany or the United Kingdom, to tap talent there.

Japanese companies are also beginning to recruit non-Japanese scientists to

their institutes in Japan. The total number is still small - 751, according to the white paper - but it has tripled in the past three years. About half come from Western Europe and the United States, and the rest from Asia.

Furthermore, the number of postdoctoral fellowships offered to foreign (mostly Western) scientists by MITI, STA and the ministry of education has risen from a few dozen several years ago to 369 this fiscal year. And the agencies plan to expand the programmes.

Despite this growing influx of Western scientists, the gap in exchange of researchers with the West on both a short- and long- term basis continues to increase because many more Japanese scientists and engineers are going to Western countries. On the other hand, 20 per cent of graduate students in Japanese universities in 1990 were from overseas, up from 10 per cent in 1985, but most are from Asian countries.

Some shortcomings do exist in Japan's globalization initiative, the white paper finds. For instance, it says that Japan's exchange of information with the United States and Europe through computer networks - such as the Scientific and Technical Information Network, which links the Chemical Abstracts Service of the United States, the Japan Information Centre of Science and Technology, and Fachinformationszentrum-Karlsruhe in Germany - is much more limited than the exchange between Europe and the United States.

The white paper also says that discrepancies in intellectual property rights among countries deter globalization of research, and it calls for making patent systems consistent. MITI has recently rewritten Japan's laws to allow foreign companies access to patents arising out of Japanese government projects they participate in.

David Swinbanks

\section{But are manufacturers still holding out?}

\section{Washington}

WHEN the customer has been a US company and the product was state-of-theart technology, Japanese manufacturers have repeatedly delayed sales, charged much higher prices or refused to sell the products at all, an 18-month investigation* by the congressional General Accounting Office (GAO) concluded last week. This finding is in marked contrast to the open attitude that Japanese government and industry are trying to encourage (see above).

About half of the 59 companies GAO interviewed (under promise of anonymity) gave examples in which Japanese refused to sell them electronic or semi- conductor-fabrication technology or delayed their orders by more than six months. One company said that its attempts to buy a piece of etching equipment were rebuffed for a year while the Japanese company said the product was still being test-marketed in Japan and that US service and English-language manuals were not yet available. Most of the US companies thought that the Japanese response was understandable, however, and argued for greater US technology independence rather than sanctions against the manufacturers.

C.A.

* US Business Access to Certain Foreign State-ofthe-Art Technology, GAO/NSIAD-91-278, September 1991.
Canada advances KAON Washington

LATE last month, the Canadian government announced that it is committing $\$ 236$ million for construction of KAON, a major upgrade of the existing TRIUMF cyclotron at the University of British Columbia. Prime Minister Brian Mulroney's administration describes the support as new money - separate from the $\$ 1,500$ million already budgeted for science and technology.

The proposed KAON accelerator would use TRIUMF (the Tri-University Meson Facility) to accelerate proton beams to 520 $\mathrm{MeV}$ and then inject them into a series of new accumulator and accelerator rings which will boost the proton beams to $\mathbf{3 0}$ $\mathrm{GeV}$. This beam will then strike a target, producing kaons, antiprotons and neutrinos. Kaons are valuable because their mean lifetimes are long enough to allow researchers to assemble enough of them to provide high statistical accuracy. Hypothesis-testing experiments that would take several years on existing facilities will take only hours on KAON.

The KAON decision has disturbed many Canadians because of the political circumstances surrounding it. British Columbia's incumbent conservative party is mired in ministerial scandals involving corruption, breach-of-trust and fraud. The announcement of the KAON award from Mulroney's federal conservative government was made hours before a provincial announcement of an election for 17 October.

TRIUMF's director Erich Vogt denies politics played a role in the timing of the announcement. He received word several weeks ago to expect good news, he said.

Others are more sceptical, given that science advisory committees have recommended against KAON unless there is a commitment of long-range support. "It does draw into question the role and function of the advisory bodies, given the unanimous recommendations not to proceed with KAON," said Janet Halliwell, chairman of the Science Council of Canada.

The federal government's decision to commit itself to KAON comes at a time when support for the project is still uncertain. When added to a previous $\$ 236$ million commitment from British Columbia, the federal commitment will promise about two-thirds of KAON's projected \$709 million capital costs, but there are no guarantees about the final one-third of capital costs or the operating expenses.

The charge that politics influenced the KAON decision rings somewhat hollow, given that the TRIUMF-KAON project has never been considered merely as science. Most politicians support it as part of an effort to redistribute institutions and facilities - and the employment opportunities they provide - across Canada.

Catherine McMullen 